\title{
EFFECT OF INTERCROPPING IN SHADING WITH CROTALARIA ON THE INITIAL DEVELOPMENT OF COFFEE TREE
}

\author{
Kleso Silva Franco Junior ${ }^{1}$, Ana Beatriz Carvalho Terra ${ }^{2}$, Ligiane Aparecida Florentino ${ }^{3}$ \\ Julian Silva Carvalho ${ }^{4}$, Bernardino Cangussu Guimarães ${ }^{5}$, Nilton de Oliveira Silva ${ }^{6}$
}

(Received: November 04, 2019; accepted: November 25, 2019)

\begin{abstract}
Coffee cultivation in Brazil is still predominantly in full sun. However, the shading technique has gained prominence to increase the sustainability and profitability of production. Coffee intercropping legumes, besides contributing to shading, act as green manure, improving soil characteristics. Thus, in this study the objective was evaluating the shading intercropping effect on the initial development of coffee trees. The experiment was carried out at Sítio Santa Felicidade, municipality of Campestre - Southern Minas Gerais. Four species of the Crotalaria genus were used and one control treatment without any intermediate species, totaling 5 treatments. The planting was carried out in 4 replicates per treatment, in a randomized block system (DBC), with 16 coffee plants per plot. The 10 central plants were used for evaluation. The variables analyzed were: seedling setting $(\%)$, plant height $(\mathrm{cm})$, leaf area index (LAI), number of plagiotropic branch internodes and 50 $\mathrm{cm}$ from ground level $\left(\mathrm{cm}^{2}\right)$, temperature $\left({ }^{\circ} \mathrm{C}\right)$ and soil moisture $(\%)$. Data were statistically interpreted by variance analysis and comparisons of averages performed by the Scott-Knott test at $5 \%$ probability, using the statistical software SISVAR ${ }^{\circ}$. It was observed that, except seedling setting (\%) wherein there was no statistical difference among treatments, the other parameters showed positive responses in intercropping with crotalaria when compared to the control, showing the beneficial effect of the use of this legume when intercropped with coffee tree.
\end{abstract}

Index terms: Coffea arabica, Plagiotropic, Soil moisture.

\section{INTRODUCTION}

Coffee originates in the deciduous forests of Ethiopia and Sudan (Boulay et al., 2000) and is therefore adapted to shade (Ricci et al., 2006). Several countries in Latin America have traditionally used the coffee shading technique to increase the sustainability and profitability of production. However, in Brazil, full sun cultivation is still predominant, representing about $90 \%$ of existing crops.

The shading technique has expanded in the country due to the need to produce with fewer inputs, as occurs in the organic system (Morais et al., 2009). Besides, shading protects against extreme temperatures, reduces production biennially, the incidence of drought and improve coffee quality (Rena \& Maestri, 1985; Vaast et al., 2005), avoiding losses in production and harming producers. In the South and Southeast, shading is less frequent, with trees generally used to protect the crop from frost or cultivated for its high economic value.

Donald (2004) states that the relation among coffee areas in full sun and shaded is directly related to the value of the grain. The increase in crop value allows the producer to intensify production by generally opting for full sun production. In this case the increase in costs is offset by the high price of coffee. On the other hand, with the drop in the market value, the producer prefers the shaded system, due to its less intensive use of inputs.

In agroforestry systems (AFS) with coffee, the crop is often associated with legumes. There is a wide variety of coffee agroforestry systems (Jaramillo-Botero et al., 2006), ranging from traditional ones, where native forest is conserved and enriched with coffee plants, to technified shade systems where coffee trees are intercropped with a single tree species, usually legume, managed with pruning over the years (Gobbi, 2000).

Some plants have shown promise when intercropped with coffee, such as Crotalaria jucea L., Cajanus cajan L. and Stilozobium aterrimun L. (Pereira, 2004). The use of these legumes, besides contributing to shading and consequent initial growth of coffee seedlings, can also act as green manures, improving the physical-chemical and biological characteristics of the soil. Thus, in this present study the objective was evaluating the shading crotalaria intercropping effect on the initial development of coffee trees.

${ }^{1}$ Centro Superior de Ensino e Pesquisa de Machado - CESEP - Av. Dr. Athaide Pereira de Souza s/n - 37.750 - 000 - Machado- MG kleso.junior@yahoo.com.br

${ }^{2,3}$ Universidade José do Rosário Vellano/UNIFENAS - Rod 179 Km 0 - 37132-440 - Alfenas -MG - anabeatriz.terra@hotmail.com, ligiane.florentino@unifenas.br

${ }_{4,5,6}$ Empresa de Assistência Técnica E Extensão Rural de Minas Gerais - EMATER MG- Av. Raja Gabaglia, 1626 - B. Gutierrez 30.441-194 - Belo Horizonte - MG - julian@emater.mg.gov.br, bernardino@emater.mg.gov.br, nilton.silva@emater.mg.gov.br 


\section{MATERIAL AND METHODS}

The experiment was carried out at Sítio Santa Felicidade, Campestre - South MG, located at the geographic coordinates: $21^{\circ} 43^{\prime} 12$ " South and $46^{\circ} 14$ ' ' $46^{\prime}$ " West, at an altitude of 1.106 meters and with a hot and temperate climate. The summer with higher rainfall than winter being classified as Cwb according to Köppen (1936) and Geiger (1954). The average annual temperature is $18.9^{\circ} \mathrm{C}$. The average annual rainfall is $1.609 \mathrm{~mm}$ according to the Clima-Date.Org ${ }^{1}$. The Result of the soil analysis carried out at the beginning of the research is represented in Table 1.

The soil is characterized as Red Latosol of medium texture, type 2 according to the classification of the Ministry of Agriculture, Livestock and Supply - MAPA (2008).

The coffee cultivar implanted was Catuai Amarelo IAC 62, seedlings with 4 pairs of leaves planted on 12/10/2017 and intercropped with the following plants: Crotalaria spectabilis (L.), Crotalaria breviflora, Crotalaria juncea (Crotalaria), Crotalaria ochroleuca and control without any intermediate species, totaling 5 treatments.

All plants of the intercropping were grown at $50 \mathrm{~cm}$ from the coffee line, to shade the coffee seedlings.

The sowing of the shading plants was performed 30 days before the coffee planting on $10 / 11 / 2017$, with a hand planter. Planting density was $4 \mathrm{~kg} \mathrm{ha}^{-1}$. The planting was carried out in 4 replicates per treatment, in a randomized block system (DBC), with 16 coffee plants per plot. The 10 central plants were used for evaluation.

Shading plants were maintained in the first year until August/2018, being sown again in December 2018 and managed until May/2019. The shading plants were kept in the first year for 8 months, being sown again in December and kept for another 5 months.

The same crop management was used for all treatments, with basic fertilization with a $\mathrm{P}_{2} \mathrm{O}_{5}$ source and well-tanned cattle manure, three $\mathrm{N}$ and $\mathrm{K}$ mulching, weed control with the use of preemergent herbicide Oxyfluorfen, 2 sprays with mineral salts and systemic fungicide.

After 17 months, the following characteristics were evaluated: seedling setting $(\%)$, plant height $(\mathrm{cm})$, leaf area index - LAI $\left(\mathrm{cm}^{2}\right)$, mean length of plagiotropic branches at 50 $\mathrm{cm}$ from the ground $(\mathrm{cm})$, number of internodes in plagiotropic branches and at $50 \mathrm{~cm}$ from the ground level $\left(\mathrm{cm}^{2}\right)$ and the soil temperature $\left({ }^{\circ} \mathrm{C}\right)$ that was always measured at 13 hours weekly, using an infrared digital laser thermometer and the soil moisture, by the gravimetric method.

The following formula was used to calculate the LAI, according to Barros et al. (1973):

$$
\mathrm{LAI}=\mathrm{C} \times \mathrm{L} \times 0.0667
$$

Data were statistically interpreted by variance analysis and comparisons of averages performed by the Scott-Knott test at 5\% probability, using the statistical software SISVAR ${ }^{\circledR}$ (Ferreira, 2014).

\section{RESULTS AND DISCUSSION}

The survival (\%) of coffee seedlings were the only that did not show a statistical difference among treatments (Table 2).

The plants average height $(\mathrm{cm})$ showed that the presence of intercropping shading had a positive response when compared to the control treatment, highlighting the species Crotalaria spectabilis and Crotalaria juncea (Table 3 ).

The increase in the plants average height, when subjected to shading, may be related to the fact that the plants lengthen the stem to avoid the low irradiance found in the environment (Taiz \& Zeiger, 2004). According to Tatagiba et al. (2010), shading induces plants to allocate most of their resources to grow in height by lengthening the internodes in search of light, inducing to etiolation. The same authors found that shading influenced seedling height, and higher shading levels provided greater height growth.

Braun et al. (2007), also found higher growth in conilon coffee seedlings at 50 and $75 \%$ shade compared to plants maintained at 30\% shade and full sun. Franco Junior \& Florentino (2019), found a positive effect on the shade treatments, and the treatments with crotalaria and guandu presented the highest plant height, being on average $35 \%$ higher than the control treatment (full sun). According to Morais et al. (2003), the accentuated growth is a mechanism called etiolation, to optimize the light capture.

The plagiotropic branches, which are the lateral and productive branches of the plant, when associated with different species of crotalaria presented higher values of average length and number of internodes when compared to the control (Table 4). According to Pezzopane et al. (2007), shading causes changes in plant physiology promoting greater branch growth. 
TABLE 1- Result of the $0-20 \mathrm{~cm}$ soil analysis carried out at the beginning of the research (coffee planting)

\begin{tabular}{ccccccc}
\hline $\begin{array}{c}\mathrm{pH} \\
\mathrm{H}_{2} \mathrm{O}\end{array}$ & $\begin{array}{c}\mathrm{P} \\
\mathrm{mgdm}^{3}\end{array}$ & $\begin{array}{c}\mathrm{K} \\
\mathrm{mgdm}^{3}\end{array}$ & $\begin{array}{c}\mathrm{Ca} \\
\mathrm{cmolc} \mathrm{dm}^{3}\end{array}$ & $\begin{array}{c}\mathrm{Mg} \\
\mathrm{cmolc} \mathrm{dm}^{3}\end{array}$ & $\begin{array}{c}\mathrm{Al} \\
\mathrm{cmolc} \mathrm{dm}^{3}\end{array}$ & $\begin{array}{c}\mathrm{H}+\mathrm{Al} \\
\mathrm{cmolc} \mathrm{dm}^{3}\end{array}$ \\
\hline 5,7 & 23,5 & 110 & 4 & 1,2 & 0,1 & 4,2 \\
\hline
\end{tabular}

TABLE 2 - Survival (\%) of coffee seedlings

\begin{tabular}{cc}
\hline Treatments & Survival (\%) \\
\hline Crotalaria spectabilis & $95 \mathrm{~A}$ \\
Crotalaria breviflora & $88 \mathrm{~A}$ \\
Crotalaria juncea & $93 \mathrm{~A}$ \\
Crotalaria ochroleuca & $90 \mathrm{~A}$ \\
Control & $78 \mathrm{~A}$ \\
\hline
\end{tabular}

*Averages followed by the same letters in the column belong to the same cluster by the Scott-Knott test at 5\% probability.

TABLE 3 - Coffee plants average height $(\mathrm{cm})$

\begin{tabular}{cc}
\hline Treatments & Height $(\mathrm{cm})$ \\
\hline Crotalaria spectabilis & $107 \mathrm{~A}$ \\
Crotalaria breviflora & $102 \mathrm{~B}$ \\
Crotalaria juncea & $111 \mathrm{~A}$ \\
Crotalaria ochroleuca & $99 \mathrm{~B}$ \\
Control & $88 \mathrm{C}$ \\
\hline
\end{tabular}

*Averages followed by the same letters in the column belong to the same cluster by the Scott-Knott test at $5 \%$ probability.

TABLE 4 - The average length of plagiotropic branches and number of internodes of plagiotropic branches of coffee at $50 \mathrm{~cm}$ of soil.

\begin{tabular}{ccc}
\hline Treatments & $\begin{array}{c}\text { Average length of plagiotropic } \\
\text { branches } \\
(\mathrm{cm})\end{array}$ & $\begin{array}{c}\text { Number of internodes of plagiotropic } \\
\text { branches }\end{array}$ \\
\hline Crotalaria spectabilis & $98 \mathrm{~A}$ & $11.1 \mathrm{~A}$ \\
Crotalaria breviflora & $92 \mathrm{~A}$ & $9.3 \mathrm{~A}$ \\
Crotalaria juncea & $99 \mathrm{~A}$ & $11.8 \mathrm{~A}$ \\
Crotalaria ochroleuca & $91 \mathrm{~A}$ & $9.2 \mathrm{~A}$ \\
Control & $82 \mathrm{~B}$ & $8.7 \mathrm{~B}$ \\
\hline
\end{tabular}

*Averages followed by the same letters in the column belong to the same cluster by the Scott-Knott test at $5 \%$ probability. 
The number of plagiotropic branch internodes is a good indicator of the number of productive nodes in a plant (Freitas et al., 2007).

Oliosi et al. (2013), also observed that shaded coffee trees presented longer plagiotropic branches, a factor associated by the authors to the internode elongation induced by low irradiance. Araújo et al. (2015), found greater etiolation of plagiotropic and orthotropic branches in coffee tree intercropped with rubber tree compared to full sun cultivation.

Franco Junior \& Florentino (2019) indicated that there was a positive effect on the number of internodes of plagiotropic branches of coffee trees associated with shade intercropping, and the treatment with crotalaria presented the highest value when compared to the others.

The etiolation is related to a lower transport speed of auxins, hormones that promote cell elongation in response to light, biosynthesized in the apical side and air tissues of plants. Higher accumulation of these hormones in the plants shoot results in greater etiolation (Gomes et al., 2008).

The leaf area index (LAI) presented a better response for the treatments in intercropping with C. spectabilis and C. juncea (Table 5). According to Bernardes et al. (1996), leaf area index and duration are the most important factors to determine dry matter production and plant growth. LAI is an important variable for estimating water, carbon and energy flows and is crucial for primary production (Barbosa et al., 2012).

Ricci et al. (2006), evaluating organic cultivation of coffee cultivars in full sun and shading, also observed that, under shading conditions, there was an increase in leaf area. According to Morais et al. (2003) that can be attributed to a mechanism used by the coffee tree to compensate for the lower light received when shaded. According to Cannell (1985), the increase in leaf area per unit area is one of the factors that influence the increase in production.

Climatic conditions (temperature and soil moisture) are shown in table 6. Treatments with the presence of Crotalaria presented lower temperatures and higher soil moisture. Boulay et al. (2000) indicated that shading provides a better climate condition for the coffee tree, protects it from stress caused by high temperatures and soil moisture loss, and reduces evapotranspiration, avoiding further defoliation during the dry season (Ricci et al., 2011).

TABLE 5 - Leaf area index of coffee plants

\begin{tabular}{cc}
\hline Treatments & $\mathrm{cm}^{2}$ \\
\hline Crotalaria spectabilis & $375.2 \mathrm{~A}$ \\
Crotalaria breviflora & $314.5 \mathrm{~B}$ \\
Crotalaria Juncea & $391.0 \mathrm{~A}$ \\
Crotalaria ochroleuca & $322.3 \mathrm{~B}$ \\
Control & $292.0 \mathrm{C}$ \\
\hline
\end{tabular}

*Average followed by the same letters in the column belong to the same cluster by the Scott-Knott test at 5\% probability.

TABLE 6 - Average temperature $\left({ }^{\circ} \mathrm{C}\right)$ and moisture $(\%)$ of soil

\begin{tabular}{ccc}
\hline Treatments & Soil temperature ${ }^{\circ} \mathrm{C}$ & Soil moisture (\%) \\
\hline Crotalaria spectabilis & $23.3 \mathrm{~A}$ & $40.2 \mathrm{~A}$ \\
Crotalaria breviflora & $22.9 \mathrm{~A}$ & $39.1 \mathrm{~A}$ \\
Crotalaria juncea & $28.9 \mathrm{~A}$ & $36.2 \mathrm{~A}$ \\
Crotalaria ochroleuca & $29.1 \mathrm{~A}$ & $34.0 \mathrm{~A}$ \\
Control & $39.2 \mathrm{~B}$ & $28.1 \mathrm{~B}$ \\
\hline
\end{tabular}

*Averages followed by the same letters in the column belong to the same cluster by the Scott-Knott test at $5 \%$ probability. 


\section{CONCLUSION}

Crotalaria intercropping showed positive responses to plant height, average length of plagiotropic branches, number of plagiotropic branch internodes at $50 \mathrm{~cm}$, leaf area index and better conditions of moisture and soil temperature.

\section{ACKNOWLEDGEMENT}

The authors would like to thank CESEP Center for Higher Education and Research, CESEP Coffee Research Center, Technical Assistance and Rural Extension Company of Minas Gerais - EMATER - MG, the Site owner, and José do Rosario Vellano University for their support and support. CAPES / PROSUP for the scholarship granted to doctoral student Ana Beatriz Carvalho Terra.

\section{REFERENCES}

ARAÚJO, A. V. et.al.; Microclima e características fisiologicas do cafeeiro Conilon, consorciado com bananeira. Coffee Science, Lavras, v. 10, n. 2, p. 214 - 222, abr./jun. 2015.

BARBOSA, J. P. R. A. D. et al. Estimativa do IAF de cafeeiro a partir do volume de folhas e arquitetura da planta. Coffee Science, Lavras, v. 7, n. 3: . 267-274, Set./Dez. 2012.

BARROS, R.S. et al. Determinação de área de folhas do café (Coffea arabica L. cv. 'Bourbon Amarelo'). Revista Ceres, Viçosa, v.20, n.107: 44-52, 1973.

BERNARDES, M.S.; CASTRO, P.R.C.; MARTINS, A.N. Formação da copa e resistência de árvores ao vento: modelo de seringueira. Piracicaba, FEALQ, 1996.88p.

BOULAY, M.; SOMARRIBA, E.; OLIVIER, A. Calidad de Coffea arabica bajo sombra de Erythrina poeppigiana a diferentes elevaciones en Costa Rica. Agroforestería en las Américas, v.7, n.1: 40-42, 2000.

BRASIL. Ministério da agricultura, pecuária e abastecimento secretaria de política agrícola instrução normativa $\mathrm{n}^{\circ} 2$, de 9 de outubro de 2008. Republicada por ter saído, no Diário Oficial [da] República Federativa do Brasil $n^{\circ}$ 197, de 10/10/2008, Seção 1, pág. 71, com incorreção no original. D.O.U., 10/10/2008 - Seção 1 REP., 13/10/2008 - Seção 1.

BRAUN, H. et al. Produção de mudas de café conilon propagadas em diferentes níveis de sombreamento. Idesia, Taparacá, v. 25, n. 3: 85-91, Sep./Dic. 2007.
CANNEL, M.G.R. Physiology of the coffee crop. In: CLIFFORD, M.N. \& WILSON, K.C. (Eds.) Coffee: botany, bio chemistry and production of beans and beverage. New York, Croom Helm, 1985. p.109-134.

DONALD, P. F. Biodiversity impacts of some agricultural commodity production systems. Conservation Biology, [S.1.], v. 18, n. 1: 17-37, Jan. 2004.

FERREIRA, D. F. Sisvar: um guia dos seus procedimentos de comparações múltiplas Bootstrap. Ciência e Agrotecnologia, v. 38, n. 2: 109-112, Mar./ Abr. 2014.

FRANCO JUNIOR, K.S.; FLORENTINO, L.A. Shading effect on coffee tree in formation stage. Coffee Science, Lavras, v. 14, n. 2: 157 - 162, Apr./Jun. 2019.

FREITAS, Z.M.T.S. et al. Avaliação de caracteres quantitativos relacionados com o crescimento vegetativo entre cultivares de café arábica de porte baixo. Bragantia, Campinas, v.66, n.2: 267-275, 2007.

GEIGER, R. Kassifikation der Klimate nach. In Landolt Börnstein Zahlenwerte und Funktionen aus Physik, Chemie, Astronomie, Geophysik und Technik, Vol. 3, Köppen W (ed). Springer: Berlin, 603-607. 1954.

GOBBI, J.A. Is biodiversity-friendly coffee financially viable? An analysis of five different coffee production systems in western El Salvador. Ecological Economics v. 33, n. 2: 267-281, May. 2000.

GOMES, I.A.C, et al.; Alterações morfofisiológicas em folhas de Coffea arabica L. cv. "Oeiras" sob influência do sombreamento por Acacia mangium Willd, Ciência Rural, v.38, n.1,109-115. jan-fev, 2008.

JARAMILLO-BOTERO, C.; MARTINEZ, H.E.P.; SANTOS, R.H.S. Características do café (Coffea arabica 1.) sombreado no norte da américa latina e no brasil: análise comparativa. Coffee Science, Lavras, v. 1, n. 2: 94-102, Jul./Dez. 2006.

KÖPPEN, W.P. Das geographische system der klimate. Gebrüder Borntraeger: Berlin. 1936.

MORAIS, H. et al. Características fisiológicas e de crescimento de cafeeiro sombreado com guandu e cultivado a pleno sol. Pesquisa Agropecuária Brasileira, Brasília, v. 38, n. 11: 1131-1137, Nov. 2003. 
MORAIS, H. et al. Sombreamento de cafeeiros durante o desenvolvimento das gemas florais e seus efeitos sobre a frutificação e produção, Ciência Rural, Santa Maria, v.39, n.2: 400-406, Mar/Abr, 2009.

OLIOSI, G.; GILES, J. A. D.; PARTELli, F. L. Comprimento de internódios e número de nós de ramos plagiotrópicos e ortotrópicos em cafeeiro conilon arborizado com cedro australiano. In: CONGRESSO BRASILEIRO DE PESQUISAS CAFEEIRAS, 39., 2013, Poços de Caldas. Anais... Brasília, DF: Embrapa Café, 2013.

PEREIRA, A.J. Produção de biomassa aérea e de sementes de Crotalaria juncea a partir de diferentes arranjos populacionais e épocas do ano. Seropedica: UFRRJ, 2004, 68p. (Dissertação de mestrado em fitotecnia), Instituto de Agronomia,Universidade Federal Rural do Rio de Janeiro, 2004.

PEZZOPANE, J. R. M. ; PEDRO JÚNIOR, M. J.; GALLO, P. B. Caracterizaçãomicroclimática em cultivo consorciado café/banana. Revista Brasileira deEngenharia Agrícola e Ambiental, Campina Grande, v. 11, n. 3, p. 256-264, 2007.
RENA, A.B.; MAESTRI, M. Fisiologia do cafeeiro. Informe agropecuário, v.11, n. 126: 26-40, Abr. 1985.

RICCI, M.S.F. et al. Cultivo orgânico de cultivares de café a pleno sol e sombreado. Pesquisa agropecuaria brasileira., Brasília, v.41, n.4: 569-575, Abr. 2006.

RICCI, M.S.F. et al. Vegetative and productive aspects of organically grown coffee cultivars under shaded and unshaded systems. Sci. agric. (Piracicaba, Braz.), Piracicaba, v. 68, n. 4: 424-430, Aug. 2011

TAIZ, L.; ZEIGER, E. Fisiologia vegetal. 3. ed. Porto Alegre: Artmed, 2004. $719 \mathrm{p}$

TATAGIBA, S.D.; PEZZOPANE, J.E.M.; REIS, E.F. Crescimento vegetativo de mudas de café arábica (Coffea arabica 1.) submetidas a diferentes níveis de sombreamento. Coffee Science, Lavras, v. 5, n. 3: 251261, Set./Dez. 2010.

VAAST, P. et al. Fruit thinning and shade improve bean characteristics and beverage quality of coffee (Coffea arabica L.) under optimal conditions. Journal of the Science of Food and Agriculture, v.86, n.2: 197-204, Oct. 2005. 